\title{
Natural radioactivity content in groundwater of Mt. Etna's eastern flank and gamma background of surrounding rocks
}

\author{
Beata Kozłowska ${ }^{1,{ }^{\star}}$, Agata Walencik-Łata ${ }^{1}$, Giuseppina Immè ${ }^{2,3}$, Roberto Catalano ${ }^{2,3}$, \\ Gabriella Mangano $^{2}$, Daniela Morelli ${ }^{2,3}$, Salvatore Giammanco ${ }^{4}$ \\ ${ }^{1}$ University of Silesia, Institute of Physics, Department of Nuclear Physics and Its Applications, Katowice, Poland \\ ${ }^{2}$ Università di Catania, Dipartimento di Fisica e Astronomia, Catania, Italy \\ ${ }^{3}$ Istituto Nazionale di Fisica Nucleare, Sezione di Catania, Catania, Italy \\ ${ }^{4}$ Istituto Nazionale di Geofisica e Vulcanologia, Osservatorio Etneo, Catania, Italy
}

\author{
Article history \\ Received May 22, 2015; accepted January 12, 2016. \\ Subject classification: \\ Groundwater processes, Radioactivity and isotopes, Chemistry of waters, Gases, Hydrogeological risk.
}

\begin{abstract}
Waters of Mt. Etna are the main source of drinking water for the local population and are also distributed in municipal supply systems to neighbouring areas. Radioactivity in underground waters and surrounding rocks from the eastern flank of Mt. Etna was investigated on the basis of 9 water and 8 rock samples from 12 localities altogether. Three samples were from water drainage galleries and six from water wells. All water intakes are used for consumption. Activity concentration of uranium isotopes ${ }^{234,238} \mathrm{U}$, radium isotopes ${ }^{226,228} \mathrm{Ra}$ and radon ${ }^{222} \mathrm{Rn}$ were determined with the use different nuclear spectrometry techniques. The determination of uranium isotopes was carried out with the use of alpha spectrometry. The measurements of radium and radon activity concentration in water were performed with the use of a liquid scintillation technique. Additionally, rocks surrounding the intakes were examined with gamma spectrometry. All water samples showed uranium concentration above Minimum Detectable Activity (MDA), with the highest total uranium $\left({ }^{234} U+{ }^{238} U\right)$ activity concentration equal to $149.2 \pm 6 \mathrm{mBq} / \mathrm{L}$. Conversely, all samples showed radium isotopes activity concentrations below MDA. Radon activity concentration was within the range from $2.91 \pm 0.36$ to $21.21 \pm 1.10 \mathrm{~Bq} / \mathrm{L}$, hence these waters can be classified as low-radon waters. Gamma natural background of the rocks surrounding the water sampling sites was found on the same levels as other volcanic rocks of Italy.
\end{abstract}

\section{Introduction}

There is a growing concern about the health effects produced by natural radioactivity in the environment. Natural radionuclides are present in water, air, soil, plants and animals and in consequence in the human diet. In groundwater, their presence is determined by their activity concentration in soil and bedrock. Groundwater reacts with the surrounding rocks and re- leases elements which can be dissolved in it. Long-lived isotopes of uranium, radium and potassium are mainly responsible for natural radioactivity content. The most extensively studied natural radionuclide in all types of natural environments is radon since this element was found to be directly or indirectly responsible of about $2 \%$ of all death from cancer in Europe [Darby et al. 2005]. In particular, indoor radon levels derived from groundwater use in the USA are thought to cause 1-7\% of fatal lung cancers [Cothern et al. 1986].

Concerning an active volcanic environment such as Mt. Etna still few detailed studies exist on the levels of radionuclides other than radon in groundwater. Waters of Mt. Etna are the main source of drinking water for the local population and are also distributed in municipal supply systems to neighbouring areas. Moreover, they are used for both agricultural and industrial purposes.

A previous study on the determination of the activity concentration of ${ }^{234,238} \mathrm{U},{ }^{226,228} \mathrm{Ra}$ and ${ }^{222} \mathrm{Rn}$ in Etna's groundwater intakes was recently carried out [Kozłowska et al. 2009] showing values of uranium isotopes generally higher than the Minimum Detectable Activity (MDA), radium isotopes generally below MDA and low radon activity concentrations. The latter were in the same range as those found by D'Alessandro and Vita [2003], who performed an extensive survey in Mt. Etna's groundwater for the specific determination of dissolved radon contents.

In this work we present geochemical data on the activity concentration of uranium isotopes ${ }^{234,238} \mathrm{U}$, radium isotopes ${ }^{226,228} \mathrm{Ra}$ and ${ }^{222} \mathrm{Rn}$ in collected un- 


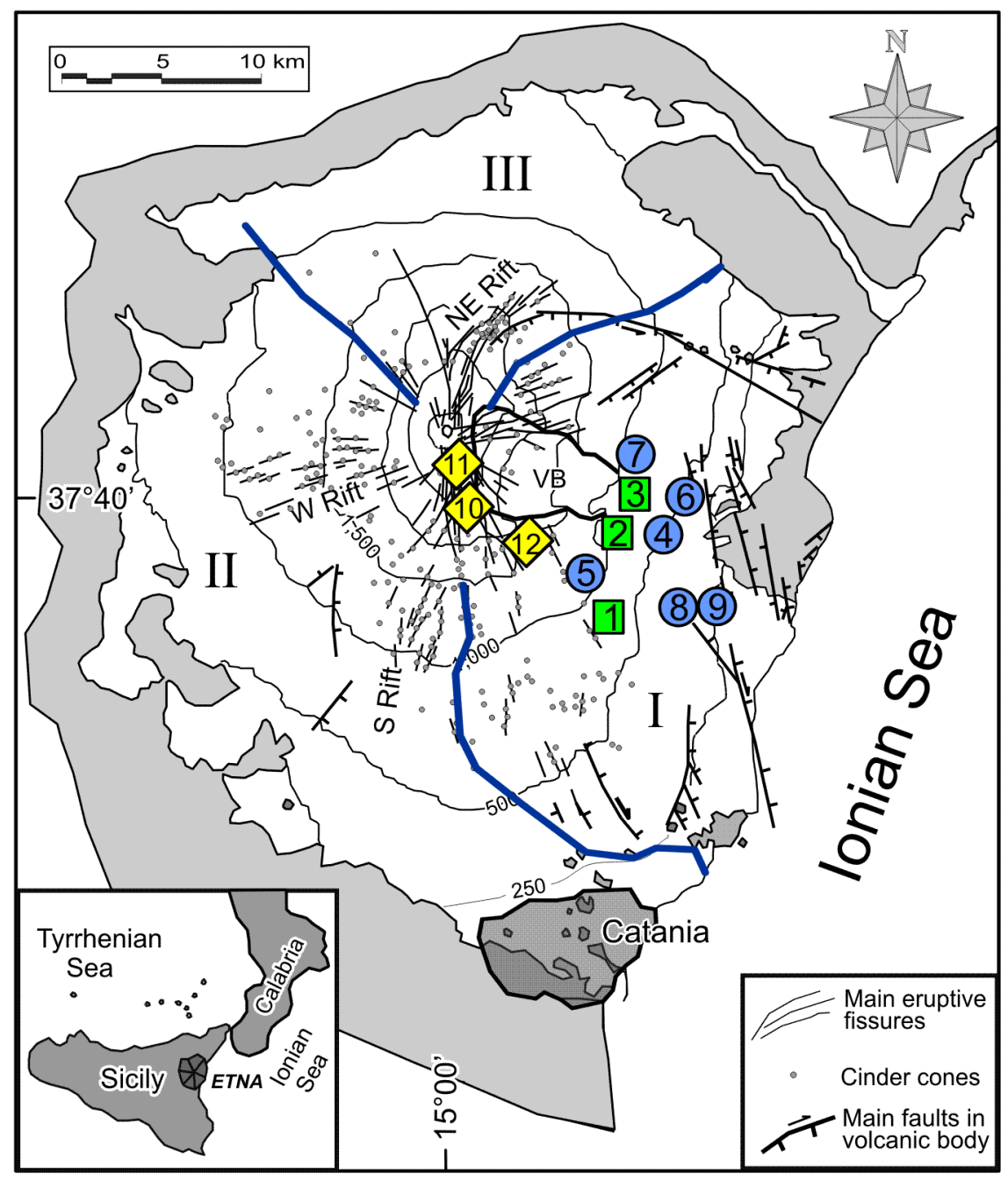

Figure 1. Map of study area and sampling sites. Green squares represent water drainage galleries; blue open circles represent water wells; yellow open diamonds indicate the location of the three lava rock samples taken near the summit area of the volcano. The three main hydrogeological basins of the volcano (I = eastern basin; II = western basin; III = northern basin, according to Ferrara [1990]), delimited by thick blue lines, are also shown together with the three main rift zones (NE Rift, W Rift and S Rift, respectively). VB = Valle del Bove morphological depression. Volcano-tectonic data of Mt. Etna modified from Acocella and Neri [2003].

derground waters from the aquifers of the eastern flank of Mt. Etna volcano. This area was selected as a good case study because it is characterised by large volumes of groundwater, strong interaction between groundwater, volcanic rocks, volcanic gases and some hydrothermal fluids [Aiuppa et al. 2000, Brusca et al. 2001, Parello et al. 2001, Aiuppa et al. 2004]; it is also the area of Mt. Etna with the highest values of dissolved radon [D'Alessandro and Vita 2003] and the only area where radium isotopes were detected [Kozłowska et al. 2009]. All these facts stimulated the authors to perform detailed studies on natural radioactivity content in groundwater from this area. Moreover, gamma spectrometry measurements were performed on five samples from volcanic rocks surrounding water intakes and three samples from volcanic rocks taken close to summit craters, in order to investigate the natural background radioactivity of the area.

\subsection{Sampling}

Nine groundwater samples from aquifers of the eastern flank of Mt. Etna were collected for the purposes of this study. We chose sampling sites whose waters are continuously used for drinking purposes by the local population and whose sampling point was not too far from the water well/drainage gallery. There were other waters available for collection but they were either not used for drinking or their closest collection point was too far from the well/drainage gallery, so there was a high chance of losing radon by radioactive decay before collection.

Sampling was performed three times, in 2011, 2012 and 2013 year. Figure 1 presents the investigated area and the sampling sites. Three samples were taken from water drainage galleries and six from water wells. In the vicinity of five of these sites rocks samples were collected for the analysis of radioactive isotopes. Besides, three more rock samples were collected from the old- 
est lavas outcropping in the uppermost slopes of the volcano, thus representing the rock types present in the recharge areas of the aquifers that contain the groundwater collected downslope. Table 1 presents a description of the intakes and the physical-chemical properties of the investigated waters, i.e. total dissolved solids (TDS), $\mathrm{pH}$, electrical conductivity and temperature. The table also shows the values of partial pressure of dissolved

\begin{tabular}{|c|c|c|c|c|c|c|c|c|c|c|}
\hline $\begin{array}{l}\text { Sample } \\
\text { code }\end{array}$ & $\begin{array}{l}\text { Sample } \\
\text { name }\end{array}$ & $\begin{array}{c}\text { Sample } \\
\text { description }\end{array}$ & $\begin{array}{l}\text { Sample } \\
\text { type }\end{array}$ & \begin{tabular}{l}
\multicolumn{1}{c}{ Rock } \\
surrounding \\
water intake
\end{tabular} & $\mathrm{pH}$ & $\begin{array}{c}\text { Dapth } \\
{[\mathrm{m}]}\end{array}$ & $\begin{array}{c}\mathrm{T} \\
\left({ }^{\circ} \mathrm{C}\right)\end{array}$ & $\begin{array}{c}\text { Conductibility } \\
{[\mathrm{mS} / \mathrm{cm}]}\end{array}$ & $\begin{array}{c}\text { TDS } \\
{[\mathrm{mg} / \mathrm{L}]}\end{array}$ & $\begin{array}{l}\mathrm{pCO}_{2} \\
{[\mathrm{~atm}]}\end{array}$ \\
\hline E_1 & Fleri & $\begin{array}{l}\text { water from } \\
\text { drainage gallery, } \\
\text { a village center, } \\
\text { public water intake, } \\
\text { drinking water }\end{array}$ & gallery & not taken & 6.51 & NA & 17.5 & 0.75 & 360 & $0.124^{\star}$ \\
\hline E_2 & $\begin{array}{c}\text { Valle } \\
\text { San Giacomo }\end{array}$ & $\begin{array}{l}\text { water from } \\
\text { drainage gallery, } \\
\text { drinking and } \\
\text { irrigation water, } \\
\text { local distribution }\end{array}$ & gallery & $\begin{array}{c}\text { sample } \\
\text { from the } \\
\text { neighborhood }\end{array}$ & 6.70 & NA & 18.85 & 1.37 & 668 & $0.026^{\star \star}$ \\
\hline E_3 & Milo & $\begin{array}{l}\text { water from } \\
\text { drainage gallery, } \\
\text { local distribution, } \\
\text { drinking water, } \\
\text { public intake }\end{array}$ & gallery & not taken & 7.54 & NA & 17.3 & 0.81 & 390 & $0.002^{\star}$ \\
\hline E_4 & Primoti & $\begin{array}{l}\text { water from } \\
\text { private well, } \\
\text { irrigation water }\end{array}$ & well & $\begin{array}{l}\text { lava and soil } \\
\text { close } \\
\text { to the well }\end{array}$ & 6.67 & 150 & 18.5 & 4.52 & 2340 & $0.633 \S$ \\
\hline E_5 & Ilice & $\begin{array}{c}\text { water - MPS, } \\
\text { local distribution } \\
\text { only, drinking water }\end{array}$ & well & $\begin{array}{c}\text { sample } \\
\text { from the } \\
\text { neighborhood }\end{array}$ & 6.55 & 120 & 18.4 & 0.74 & 357 & $0.124^{\star}$ \\
\hline E_6 & $\begin{array}{l}\text { Macchia } \\
\text { di Giarre }\end{array}$ & $\begin{array}{l}\text { water from } \\
\text { well San Paolo, } \\
\text { drinking water, } \\
\text { public intake }\end{array}$ & well & not taken & 6.86 & 100 & 17.8 & 2.73 & 1360 & $0.022^{\star \star}$ \\
\hline E_7 & Fornazzo & $\begin{array}{l}\text { water - MPS, } \\
\text { drinking water, } \\
\text { local distribution, } \\
\text { private intake }\end{array}$ & well & $\begin{array}{c}\text { sample } \\
\text { from the } \\
\text { neighborhood }\end{array}$ & 7.61 & $>100$ & 17.4 & 0.81 & 391 & $0.010^{\star}$ \\
\hline E_8 & Linera & $\begin{array}{l}\text { water used only } \\
\text { for irrigation, } \\
\text { private intake }\end{array}$ & well & not taken & 6.39 & $>100$ & 17.2 & 2.01 & 987 & $0.120^{\star \star}$ \\
\hline E_9 & Guardia & $\begin{array}{c}\text { water for } \\
\text { drinking and } \\
\text { irrigation, } \\
\text { local distribution, } \\
\text { public intake }\end{array}$ & well & $\begin{array}{c}\text { sample } \\
\text { from the } \\
\text { neighborhood }\end{array}$ & 6.40 & $>100$ & 19.0 & 1.54 & 756 & $0.156^{\star}$ \\
\hline E_10 & $\begin{array}{c}\text { La Montagnola } \\
\text { crater }(1763)\end{array}$ & - & & rock sample & & & & & & \\
\hline E_11 & $\begin{array}{c}\text { Piano } \\
\text { del Lago }\end{array}$ & - & & rock sample & & & & & & \\
\hline$E_{-} 12$ & $\begin{array}{c}1792 \\
\text { lava flow }\end{array}$ & - & & rock sample & & & & & & \\
\hline
\end{tabular}

Table 1. Physical-chemical properties of investigated waters and samples description. NA = not available; MPS=municipal power supply; ${ }^{\star} \mathrm{pCO}_{2}$ values from Parello et al. [2001]; ${ }^{\star \star} \mathrm{pCO}_{2}$ values from Giammanco et al. [1998]; $\S$ average $\mathrm{pCO}_{2}$ value for this site, from Giammanco et al. [2007a]. 
$\mathrm{CO}_{2}\left(\mathrm{pCO}_{2}\right)$ measured in the corresponding sites during previous hydrogeochemical surveys [Giammanco et al. 1998, Parello et al. 2001, Giammanco et al. 2007a].

For radium and uranium determination the samples were collected in 2 and 0.5 volume polyethylene bottles, respectively. Samples were acidified to prevent the precipitation of iron as ferric hydroxide in the collecting containers. The initial chemical treatment for radium isotopes was performed at the Department of Physics and Astronomy of the University of Catania, Italy. Further treatment of the samples for radium and uranium determination was performed at the Department of Nuclear Physics and Its Applications, Institute of Physics, University of Silesia in Katowice, Poland.

For radon determination, samples of the volume of $10 \mathrm{ml}$ were collected by disposable syringes directly at the intakes and immediately put into scintillation vials under $10 \mathrm{ml}$ of scintillation cocktail [Suomela 1993a]. The measurements were performed at the Department of Physics and Astronomy of the University of Catania.

\subsection{Hydrogeology and hydrochemistry of the area}

The investigated area is the eastern flank of Mt. Etna volcano (Figure 1). The volcanic edifice of Mt. Etna has grown up during the last 500,000 years on the eastern coast of Sicily (southern Italy) with the alternate superimposition of lava flows and pyroclastic deposits [Romano 1982, Chester et al. 1985]. During the last 5000 years Etna has been almost continuously erupting and has emitted volcanic products essentially made of lavas, ranging in composition from alkali-basalt to hawaiite [Chester et al. 1985]. The volcano built up its edifice over a sedimentary substratum with an estimated thickness greater than $15 \mathrm{~km}$, according to Cristofolini et al. [1979]. This basement is mostly composed of clays of Messinian age to the East and South and of clay, marl and quartz-arenite units, aging from Triassic to upper Pliocene, to the West and North.

In general, Etna presents a hydrogeological situation common to many other basaltic volcanoes: fissured and highly permeable lava layers are interbedded with discontinuous layers of scarcely permeable pyroclastics. These volcanic products are superimposed on an impermeable sedimentary substratum, with permeability coefficients ranging from $10^{-7}$ to $10^{-13} \mathrm{~cm} / \mathrm{s}$ [Schilirò 1988]. The base of the main aquifers of Etna thus lies at the contact between the volcanic rocks and these sediments [Ogniben 1966, Ferrara and Pappalardo 2008, Branca and Ferrara 2013]. The volcanic rocks hosting the aquifer under study basically include most of the lithotypes found on Mt. Etna. They mainly belong to more or less differentiated products of the alkaline (sodic) series [Cristofolini and Romano 1982, Ro- mano 1982, Chester et al. 1985, Branca and Ferrara 2013]. However, the concurrent presence of alkali olivine basalts ranging from "transitional" to sub-alkaline, belonging to the deepest basal lavas, is highly probable [Branca and Ferrara 2013].

Both of these magmatic series have a chemical composition ranging from basic to intermediate. The main mineralogical phases present in such products consist, in order of abundance, of plagioclase $(\sim 65 \%$, with a variable composition), pyroxene ( $\sim 28 \%$, having an average augitic composition), olivine $(\sim 3 \%)$ and oxides $(\sim 3 \%)$ such as magnetite and sometimes titanomagnetite and ilmenite. Other minerals present to a lesser extent are apatite, alkali feldspars and in some cases nepheline, leucite and biotite [Cristofolini and Romano 1982, Romano 1982, Chester et al. 1985].

According to the model first proposed by Anzà et al. [1989], Etna's groundwaters are of meteoric origin, based on their Deuterium/Hydrogen and ${ }^{18}$ Oxigen $/{ }^{16}$ Oxigen isotopic ratios. When rain waters enter the aquifer, they become enriched in $\mathrm{CO}_{2}$ which, according to the $\delta^{13} \mathrm{C}$ values already available in literature, is mostly of magmatic origin [Allard et al. 1997, Aiuppa et al. 2004]. This process is ubiquitous on Mt. Etna, although it is enhanced in the most fractured and seismically active zones of the volcano (i.e. the SW and the E flanks) and it seems to mask any evolution of water chemistry from recharge to discharge areas [Aiuppa et al. 2004, and literature therein cited].

On the basis of structural, geological and geophysical data, three main hydrogeological basins were identified [Ogniben 1966, Ferrara 1990] (Figure 1). They roughly correspond to three sectors of the volcano: I) the eastern one, tributary of the Ionian Sea; II) the southwestern one, tributary of the Simeto River; III) the northern one, whose waters feed the Alcantara River.

The general chemical composition of Etna's groundwater ranges from bicarbonate alkaline-earth to bicarbonate alkaline [Anzà et al. 1989, Dongarrà et al. 1993, Giammanco et al. 1996, Aiuppa et al. 2004]. As regards the major species in solution, the relative abundance is generally $\left(\mathrm{Na}^{+}, \mathrm{Mg}^{++}\right)>\mathrm{Ca}^{++}>\mathrm{K}^{+}$among the cations, with magnesium prevailing on sodium in the waters with higher salinity, whereas among the anions bicarbonate $\left(\mathrm{HCO}_{3}^{-}\right)$is always the prevailing dissolved species. Only very few samples show a chloride-sulphate alkaline-earth composition, normally due to the high concentrations of sulphate ions.

Values of Total Dissolved Solids (TDS) are normally well correlated with the corresponding values of calculated partial pressure of $\mathrm{CO}_{2}\left(\mathrm{pCO}_{2}\right)$ in equilibrium with water. This indicates a strong chemical interaction among meteoric water, the host rocks, from 
which the ions in solution were extracted by leaching, and a gaseous phase mainly composed of $\mathrm{CO}_{2}$. This gas is very abundant both in the ground waters and in the soils of Etna, besides its massive emission through the volcanic plume [Allard et al. 1991, Giammanco et al. 1995, D'Alessandro et al. 1997], and its origin is mostly magmatic [Anzà et al. 1989, Giammanco et al. 1995]. Dongarrà et al. [1993] also showed that the concentration of the major species in solution and particularly the calculated values of partial pressure of $\mathrm{CO}_{2}$ with which waters equilibrated can be subject to marked variations in time. Such variations were found to be caused both by seasonal effects and, more significantly, by changes in the volcanic activity of Etna. Some minor chemical species are brought into water directly from the rocks or from the volcanic gases that carry them as volatile species. This is the case of radon, that is present both in the volcanic rocks of Mt. Etna and in the volcanic gases that leak through the flanks of the volcano along tectonic faults [e.g., Neri et al. 2011].

The surface of the area investigated by our samplings was about $120 \mathrm{~km}^{2}$. The geological features of this area mainly consist of Etna's volcanic products. The volcanic rocks that outcrop in the study area are essentially represented by lava flows belonging to the so-called Stratovolcano Supersynthem, whose activity started from $57 \mathrm{ka}$ [Branca et al. 2011], although some minor outcrops belong to the Timpe Supersynthem, that started some $220 \mathrm{ka}$ [Branca et al. 2011]. All of the samples of volcanic rocks collected belong to the former.

\section{Measurement techniques}

\subsection{Water samples analysis}

Since this project is a continuation of the research started in year 2009 the measurement techniques used for water samples studies were already described in the previous publication [Kozłowska et al. 2009]. There were two nuclear spectrometry techniques involved: liquid scintillation counting and alpha spectrometry. Determination of radon activity concentration was performed at the Department of Physics and Astronomy of University of Catania with the use of Beckman LS6500 liquid scintillation counter. The radium content in water samples was measured with the use of the WinSpectral $1414 \alpha / \beta$ liquid scintillation counter from Wallac at the Institute of Physics, University of Silesia, Katowice, Poland. The measurements of uranium ${ }^{234,238} \mathrm{U}$ isotopes were carried out with the use of alpha spectrometers 7401VR from Camberra-Packard also at the Institute of Physics in the University of Silesia.

Radon activity concentration was determined using a calibrated window for alpha counting. The Min- imum Detectable Activity (MDA) was calculated according to Currie's publication [Currie 1968] and was equal to $1 \mathrm{~Bq} / \mathrm{L}$ at $1800 \mathrm{~s}$ counting time. Radium was co-precipitated with barium into $\mathrm{Ba}(\mathrm{Ra}) \mathrm{SO}_{4}$ according to radiochemical procedure based on the Polish Norm [1989]. The precipitate with radium was transferred into a scintillation vial, mixed with water and gellation scintillator. Theoretical calculations were based on Bateman's equations [Bateman 1910]. MDA was equal to $10 \mathrm{mBq} / \mathrm{L}$ for ${ }^{226} \mathrm{Ra}$ and $20 \mathrm{mBq} / \mathrm{L}$ for ${ }^{228} \mathrm{Ra}$ at $3600 \mathrm{~s}$ counting time and $3 \mathrm{~L}$ sample volume. The separation of uranium from other radionuclides present in water was performed based on the procedure worked out by Suomela [1993b]. The $\alpha$-spectrometry source was prepared by uranium co-precipitation with $\mathrm{NdF}_{3}$ and deposition on polypropylene discs $(0.1 \mu \mathrm{m})$ according to the procedure worked out by Sill [1987]. MDA was equal to 0.4 and $0.6 \mathrm{mBq} / \mathrm{L}$ for ${ }^{234,238} \mathrm{U}$ isotopes, respectively, for a 2 day counting time.

The applied methods were described in detail elsewhere [Kozłowska et al. 2009, 2010, 2012]. The methods for isotopes determination in water samples were tested during proficiency tests organized by international authorities [Möbius and Salonen 2002, IAEA 2010].

\subsection{Volcanic rocks samples analysis}

The studies of volcanic rocks samples were carried out both in the Department of Physics and Astronomy of University of Catania in Italy and in the Department of Nuclear Physics and Its Applications of the Institute of Physics at the University of Silesia in Poland. Apart from scientific purposes these studies served as intercomparison measurement in the two laboratories. Collected samples were transferred to the laboratory in the Department of Physics and Astronomy of University of Catania where they were characterized, dried, crushed and ground to a fraction smaller than $0.2 \mathrm{~mm}$ for homogenization.

The measurements in both laboratories were carried out in Marinelli geometry, in $0.6 \mathrm{dm}^{3}$ containers, where the rock samples were sealed for 30 days in order to allow secular equilibrium in the uranium and thorium series. The natural radioactivity of ${ }^{226} \mathrm{Ra},{ }^{228} \mathrm{Ra}\left({ }^{228} \mathrm{Ac}\right)$ and ${ }^{40} \mathrm{~K}$ in collected samples were determined using HPGe gamma spectrometers produced by ORTEC Company. The spectra were analyzed with the use of GENNIE gamma acquisition program and GANNAS spectra analysis program and MAESTRO-32 software. The energy calibration and the detector efficiency curves were obtained on the basis of standards prepared from certified materials from the International Atomic Energy Agency from Vienna, Austria and Central Laboratory for Radiological Protection from Warsaw, Poland. 


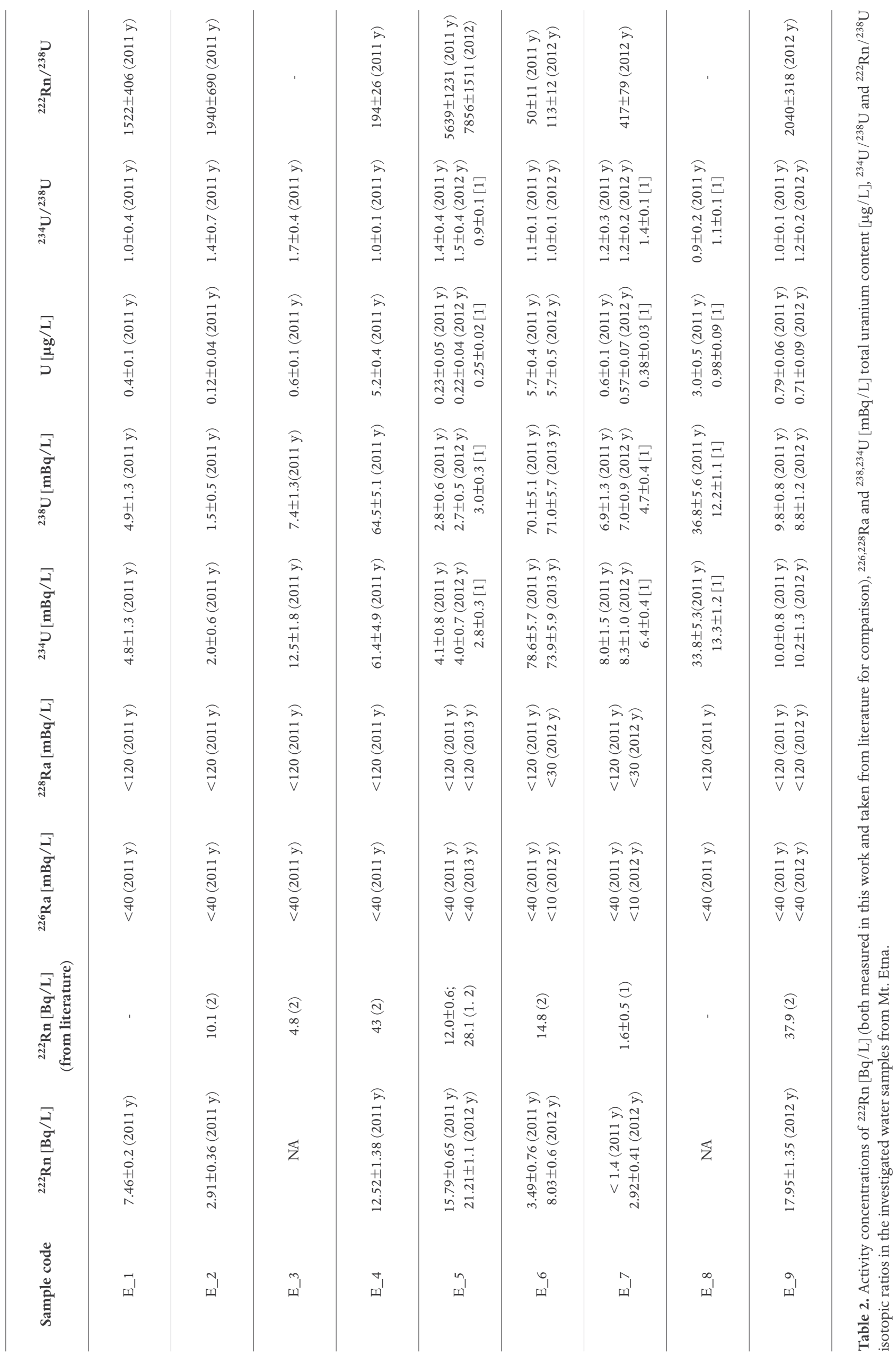


The activity of ${ }^{226} \mathrm{Ra}$ was calculated as the weighted mean of the values obtained directly from the 186.2 $\mathrm{keV}$ line and the activities of ${ }^{214} \mathrm{~Pb}(241.9,295.2,351.9$ $\mathrm{keV})$ and ${ }^{214} \mathrm{Bi}(609.3,1120.3 \mathrm{keV})$ isotopes. The determination of the presence of ${ }^{228} \mathrm{Ra}$ and calculation of its activity was based on the following gamma-ray transitions: ${ }^{212} \mathrm{~Pb}(238.6,300.1 \mathrm{keV}),{ }^{228} \mathrm{Ac}(338.3,911.1,968.9$ $\mathrm{keV}) .{ }^{40} \mathrm{~K}$ was calculated from one $1460 \mathrm{keV}$ line. The detection limit for radium measurements was $1 \mathrm{~Bq} / \mathrm{kg}$ and $10 \mathrm{~Bq} / \mathrm{kg}$ for potassium ${ }^{40} \mathrm{~K}$.

\section{Results and discussion}

The results of the analyses of groundwater and volcanic rocks collected in the present survey for the detection of radionuclides are described in the following sections relatively to uranium isotopes, radium and radon and reported in Table 2 and corresponding figures.

\subsection{Uranium}

The activity concentrations for uranium isotopes varied from $1.5 \pm 0.5 \mathrm{mBq} / \mathrm{L}$ to $71.0 \pm 5.7 \mathrm{mBq} / \mathrm{L}$ for ${ }^{238} \mathrm{U}$ and from $2.0 \pm 0.6$ to $78.6 \pm 5.7 \mathrm{mBq} / \mathrm{L}$ for ${ }^{234} \mathrm{U}$. A strong positive correlation (Pearson's correlation coefficient $r=+0.99$ ) was observed between the concentration of ${ }^{238} \mathrm{U}$ and its daughter ${ }^{234} \mathrm{U}$. Moreover, a highly significant positive correlation $(\mathrm{r}=+0.85)$ between the total uranium content in water and TDS values was also noted. The highest total uranium $\left({ }^{234} \mathrm{U}+{ }^{238} \mathrm{U}\right)$ activity concentration was equal to $149.2 \pm 6 \mathrm{mBq} / \mathrm{L}$, that is slightly higher than usual European values [Kozłowska et al. 2008, Walencik et al. 2012 and references herein]. Moreover, comparing the present results with uranium data published for 17 brands of drinking waters collected in the whole Italy one can state that they are comparable to the values obtained by Jia et al. [2009]. Our results confirm those of previous geochemical surveys of Mt. Etna groundwaters, underlining the important role both of uranium enrichment in water through rock leaching and of the redox state of water in controlling the dissolution of uranium [Aiuppa et al. 2000]. This element is actually characterized by high mobility in the aqueous system under oxidized conditions, because it forms soluble oxo-hydroxo complexes in its higher oxidation state (VI). Among the most common complexes in equilibrium with Mt. Etna waters are the uranyl-carbonates [Aiuppa et al. 2000]. This process would explain the highest uranium values found in this study. However, under more reduced conditions of waters, uranium can be scavenged by iron minerals and ferric oxyhydroxide, thus resulting to be depleted in those waters. This second process would explain the lowest uranium values found in our samples.

Interesting results were obtained for the ${ }^{234} \mathrm{U} /{ }^{238} \mathrm{U}$ activity ratios in the studied waters (Table 2, column 9), as they can be interpreted in terms of possible interference between groundwater and local precipitations (rain/melted snow) that easily percolate through highly permeable lava layers along major faults in the eastern flank of the volcano. The values varied in the range from $0.9 \pm 0.2$ to $1.7 \pm 0.4$, with values of arithmetic mean and median equal to 1.2 and 1.1, respectively. The results suggest achievement of secular equilibrium state for uranium isotopes (both arithmetic mean and median values are close to 1 ), rather than preferential leaching of ${ }^{234} \mathrm{U}(\mathrm{VI}+)$ atoms from the mineral lattice of the host rocks, apparent for the disequilibrium state. Our results confirm a previous study performed for the Mt. Etna aquifers, where the highest value of ${ }^{234} \mathrm{U} /{ }^{238} \mathrm{U}$ was equal to $1.4 \pm 0.1$ [Kozłowska et al. 2009]. As regards waters studied in the rest of Italy [Jia et al. 2009], the authors observed a slight disequilibrium between ${ }^{234} U$ and ${ }^{238} \mathrm{U}$ activity concentration in most of the water samples, with mean isotopic activity ratios of $1.35 \pm 0.33$. In the literature, groundwater flowing through rocks characterized by heterogeneous structure (e.g. presence of several deep faults and fractures) and where different weather conditions may also play a role, show ${ }^{234} \mathrm{U} /{ }^{238} \mathrm{U}$ values up to 30 [Osmond et al. 1983].

Plotting the ${ }^{234} \mathrm{U} /{ }^{238} \mathrm{U}$ ratio versus the inverse of total uranium content $1 / \mathrm{U}$ (expressed as $1 / \mu \mathrm{g}$ ) it is possible to infer processes that occur in waters in time. Groundwater characterized by constant ${ }^{234} \mathrm{U} /{ }^{238} \mathrm{U}$ values but variable contents of reversed uranium $(1 / U)$ in time is likely affected by mixing with other water devoid of uranium, such as, for example, fresh rainwater. Figure 2 presents the relation between ${ }^{234} \mathrm{U} /{ }^{238} \mathrm{U}$ and $1 / U$ for some of our studied waters (i.e., those for which analyses were repeated twice or three times). The plot indicates only minor mixing between the selected groundwater samples and shallow infiltration waters, probably rainwater or surface runoff produced from melting of snow during early spring. Moreover, the variation of $1 / U$ with time seems to be particularly evident only for the waters sampled at higher altitude (i.e., samples E_5 and E_7), thus confirming such hypothesis.

Besides activity concentrations, Table 2 presents also the results of uranium mass expressed in $[\mu \mathrm{g} / \mathrm{L}]$, since the consumption limits are given in these units. In 2011, the World Health Organization (WHO) proposed a limit for ${ }^{238} \mathrm{U}$ in groundwater equal to $30 \mu \mathrm{g} / \mathrm{L}(0.19 \mathrm{~Bq} / \mathrm{L})$, based on the chemical toxicity of uranium as recommended by EPA [2000]. Our investigated waters are used for drinking purposes, so the calculation of the effective doses due to uranium absorption seems to be reasonable. Assuming a consumption of $2 \mathrm{~L}$ of water per day per person, based on the highest uranium activity con- 


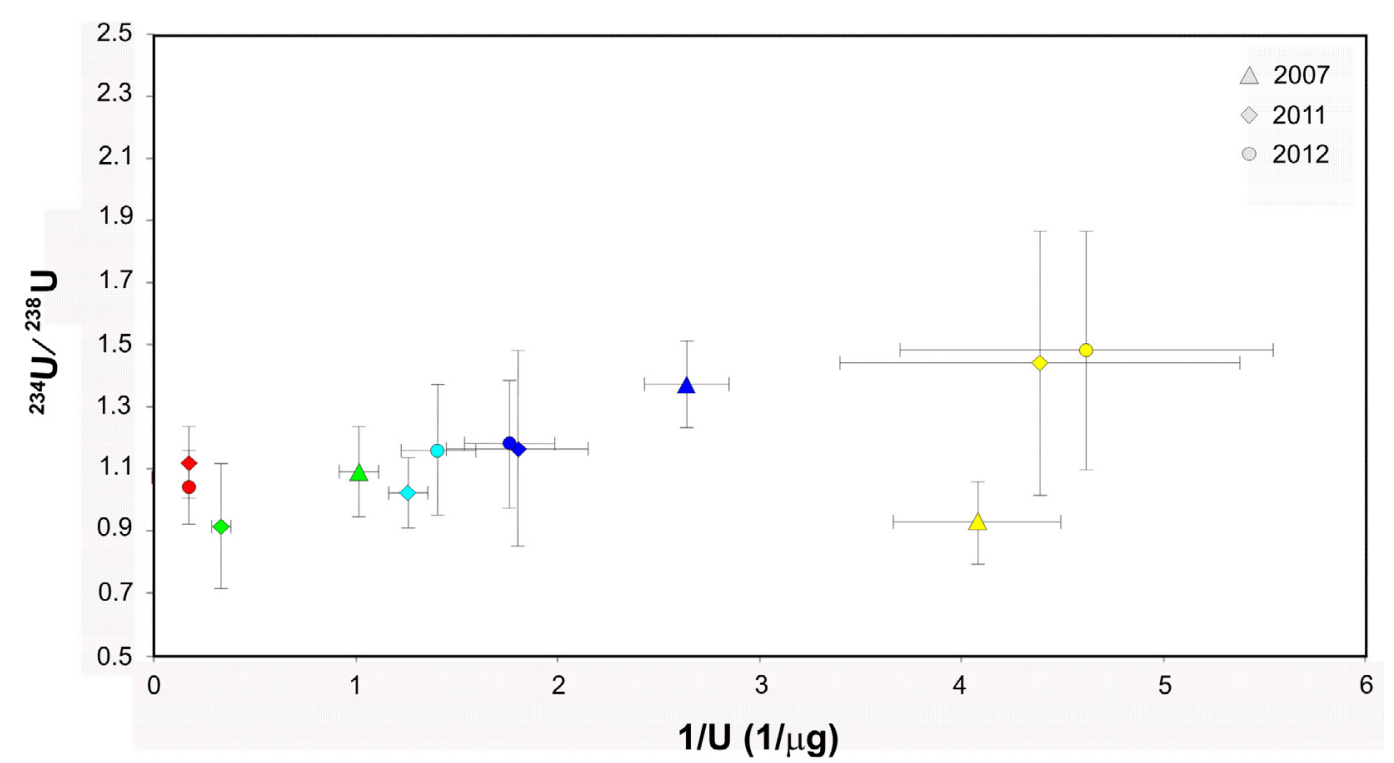

Figure 2. Graphical correlation between ${ }^{234} \mathrm{U} / 238 \mathrm{U}$ activity ratios and the inverse of uranium concentration values $(1 / \mathrm{U})$ in investigated waters from the eastern flank of Mt. Etna in three different years of sampling (data for 2007 survey are taken from Kozłowska et al. [2009]; data for 2011 and 2012 surveys are from this work).

centration measured in our samples one can calculate a yearly effective dose of $5.1 \mu \mathrm{Sv}$, which is much below the proposed limit of $100 \mu \mathrm{Sv} /$ year [WHO 2011].

\subsection{Radium and gamma background}

All water samples analysed in this study showed activity concentrations of radium isotopes ${ }^{226,228} \mathrm{Ra}$ below MDA. This is in apparent contrast with the general rule that high TDS values, such as those found in the investigated groundwater, correspond to high radium activity concentrations [Martín Sánchez et al. 1999, Dávila Rangel et al. 2002, Kralik et al. 2003, Godoy and Godoy 2006, Kozłowska et al. 2008]. On the other hand, activity concentrations of radium isotopes in other Italian waters [Jia et al. 2009] were also mostly below $10 \mathrm{mBq}$ for both isotopes. Our previous hypothesis [Kozłowska et al. 2009] was that these results may point to a low radium content in the host rocks of Etna's aquifers.

We performed gamma spectrometry measurements on rock samples collected in the vicinity of the water intakes sampled in this study. Activity concentrations of ${ }^{226} \mathrm{Ra}$ varied from $45.5 \pm 2.2 \mathrm{~Bq} / \mathrm{kg}$ to $85.2 \pm 4.4$ $\mathrm{Bq} / \mathrm{kg}$, with average value of $61.8 \mathrm{~Bq} / \mathrm{kg}$. This value is almost identical to the median $(61.4 \mathrm{~Bq} / \mathrm{kg})$, which confirms the normal distribution of the data. The activity concentration of ${ }^{228} \mathrm{Ra}\left({ }^{228} \mathrm{Ac}\right)$ varied from $28.8 \pm 0.9$ $\mathrm{Bq} / \mathrm{kg}$ to $67.7 \pm 2.6 \mathrm{~Bq} / \mathrm{kg}$, with average $53.3 \mathrm{~Bq} / \mathrm{kg}$ and median $47.2 \mathrm{~Bq} / \mathrm{kg}$. The content of ${ }^{40} \mathrm{~K}$ in the studied samples varied from $331 \pm 15 \mathrm{~Bq} / \mathrm{kg}$ to $725 \pm 35 \mathrm{~Bq} / \mathrm{kg}$. Our measured values, together with average values from other Italian magmatic rocks taken from literature for comparison, are presented in Figure 3.

Our study showed that the activity concentrations of ${ }^{226} \mathrm{Ra}$ and ${ }^{228} \mathrm{Ra}\left({ }^{228} \mathrm{Ac}\right)$ found in the rocks of Mt. Etna are on the same levels as the average European values found in bedrock. IARC [1988] comprehensive studies concluded that ${ }^{226} \mathrm{Ra}$ concentrations in soils span several orders of magnitude, but they are generally comprised between 10 and $50 \mathrm{~Bq} / \mathrm{kg}$, with an estimated average concentration of $25 \mathrm{~Bq} / \mathrm{kg}$. Similar values, from 10 to $100 \mathrm{~Bq} / \mathrm{kg}$, can be found in other publications [Cothern and Smith 1987, Nevissi and Bodansky 1987, Polański 1988]. An average of $25.3 \mathrm{~Bq} / \mathrm{kg}$ for ${ }^{226} \mathrm{Ra}$ and of $24.4 \mathrm{~Bq} / \mathrm{kg}$ for ${ }^{228} \mathrm{Ra}$ can be found in soils of Poland [Radiological Atlas of Poland 2012]. By comparison, the Agency for Toxic Substances and Disease Registry reported on its web site concentrations of ${ }^{226} \mathrm{Ra}$ in soils of northern Italy in the range $3-140 \mathrm{~Bq} / \mathrm{kg}$, excluding regions with extremely high levels of natural radioactivity.

Recently, Plant et al. [2003] stated that recent volcanic rocks such as those on Mt. Etna slopes, may be rich in uranium, which should result also in high radium contents. Chiozzi et al. [2001] published values of uranium levels in Lipari and Vulcano islands and Chiozzi et al. [2003] did the same for Stromboli, Salina, Filicuidi and Panarea islands. These data were based on gamma spectrometric measurements of ${ }^{214} \mathrm{Bi}$ line $(1.76$ $\mathrm{MeV})$ or ${ }^{208} \mathrm{Tl}$ line $(2.62 \mathrm{MeV})$ so these results are representative of ${ }^{226} \mathrm{Ra}$ or ${ }^{228} \mathrm{Ra}$ radioactive decay, rather than that of uranium or thorium, for which radioactive equilibrium had to be assumed. Converting the results of Chiozzi et al. [2001, 2003] from ppm to $\mathrm{Bq} / \mathrm{kg}$, we obtain ${ }^{226} \mathrm{Ra}$ values from 32 to $240 \mathrm{~Bq} / \mathrm{kg}$ for Lipari and Vulcano and from 14 to $117 \mathrm{~Bq} / \mathrm{kg}$ in the other volcanic islands of the Aeolian arc. Following the same procedure, we obtain ${ }^{228} \mathrm{Ra}$ values in the range $37-268 \mathrm{~Bq} / \mathrm{kg}$ 


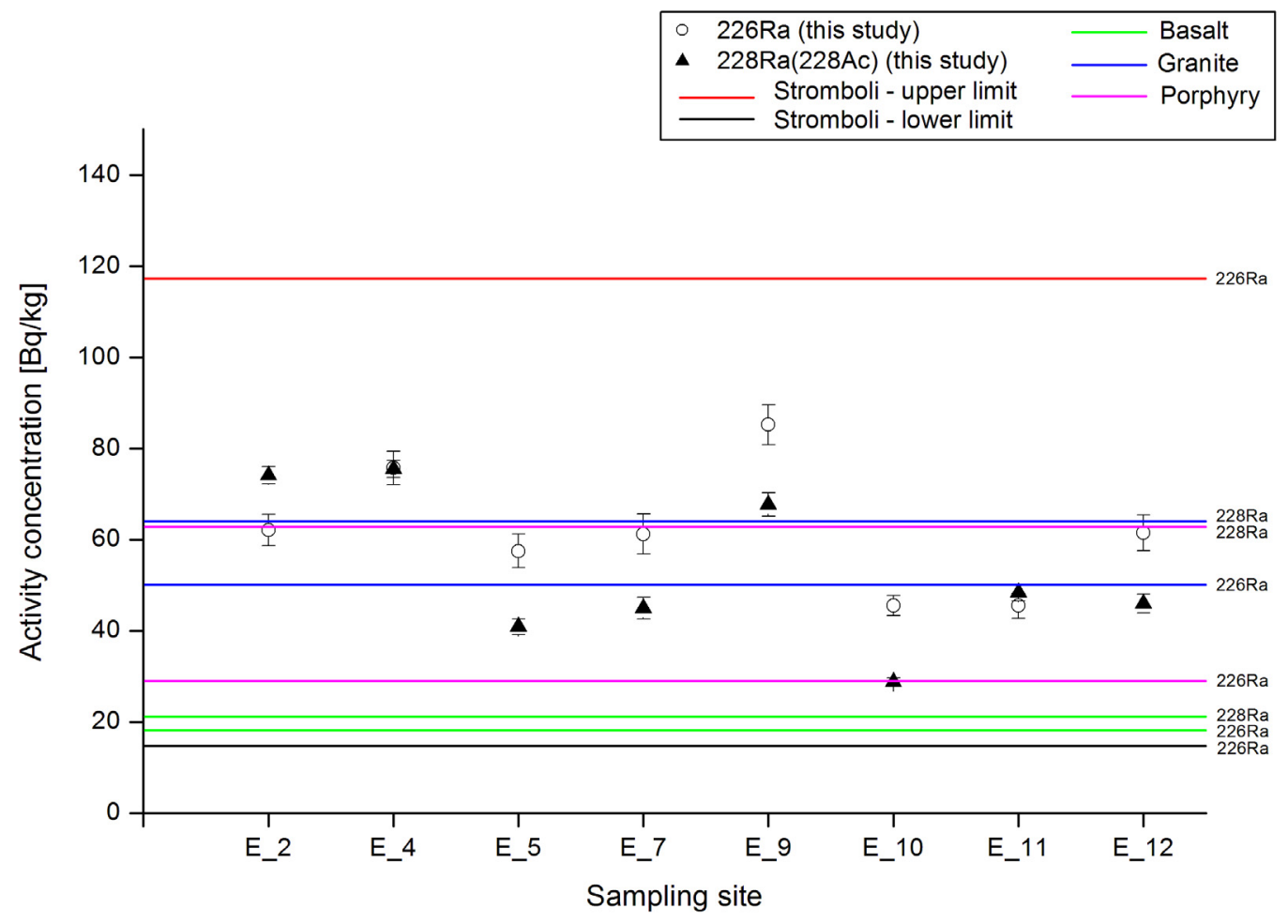

Figure 3. Activity concentrations of ${ }^{226} \mathrm{Ra}$ (open circles) and ${ }^{228} \mathrm{Ra}\left({ }^{228} \mathrm{Ac}\right)$ (filled triangles) in $[\mathrm{Bq} / \mathrm{kg}]$ in the rocks/ soil samples surrounding the water intakes sampled in this work. Activity values were obtained from $\gamma$-spectrometry analyses. For comparison, the range of the results for Stromboli is presented [Chiozzi et al. 2003], together with average values from other Italian magmatic rocks [ANPA 2000, ARPA Piemonte 2006].

for Lipari and Vulcano and $15-113 \mathrm{~Bq} / \mathrm{kg}$ for the other Aeolian volcanoes.

Brai et al. [2002], using gamma spectrometry, investigated rock samples from Stromboli island obtaining similar results as those of Chiozzi et al. [2003] ${ }^{226} \mathrm{Ra}$ values in the range $31-112 \mathrm{~Bq} / \mathrm{kg}$ and ${ }^{228} \mathrm{Ra}$ (from ${ }^{228} \mathrm{Ac}$ line) values from 30 to $106 \mathrm{~Bq} / \mathrm{kg}$ ). It seems that the activity concentrations of ${ }^{226,228} \mathrm{Ra}$ obtained for Mt. Etna rock samples in our study are very similar to the average results obtained for Stromboli, but slightly lower than those of Lipari and Vulcano. Volcanic products from the latter islands are richer in a wide variety of chemical elements, mostly silica, and hence they may be richer also in radioactive elements from the uranium chain, thus justifying the observed differences with Mt. Etna. This hypothesis is also supported by the results of D'Alessandro and Vita [2003], who found a significant positive correlation between median radon content in volcanic groundwater from several active volcanic areas of southern Italy (Mt. Etna, Vulcano, Pantelleria, Ischia) and the median total uranium content in the respective local reservoir rocks, with uranium being in turn more enriched in silica-rich volcanic rocks. As regards the apparent similarities between Mt. Etna and Stromboli, despite the two volcanoes are quite different in terms both of chemical composition of eruptive products and of styles of activity, these could be explained by a similar behaviour of Ra en- richment in the erupted fraction of the magmas from the two volcanoes by processes of magma formation, differentiation and eruption, as modelled by Capaldi et al. [1976], thus indicating similar pre-eruption histories for the magmas at both volcanoes.

In any case, the low radium activity in the groundwater of Mt. Etna would be explained mostly by the low affinity of this element for the aqueous environment, as radium tends instead to remain in the host rocks of the aquifers [Walencik et al. 2010]. Furthermore, as for uranium, the behaviour of radium in the aqueous environment is strongly controlled by redox conditions. Actually, under the typical Eh and pH conditions of groundwater of Mt. Etna, radium tends to form soluble $\mathrm{Ra}^{2+}$ ions. However, in the presence of significant amounts of sulphate and/or carbonate ions in solution, insoluble complexes such as $\mathrm{RaSO}_{4}$ or $\mathrm{RaCO}_{3}$ are likely to form, thus removing radium from water. This process could be very efficient in the sampled waters, thus contributing to lower the contents of this element in solution.

\subsection{Radon}

The activity concentration of ${ }^{222} \mathrm{Rn}$ varied from $2.91 \pm 0.36 \mathrm{~Bq} / \mathrm{L}$ to $21.21 \pm 1.1 \mathrm{~Bq} / \mathrm{L}$. Obtained radon values are comparable to those of previous ground water surveys at Mt. Etna [D'Alessandro and Vita 2003, Kozłowska et al. 2009]. The variations in radon activity 


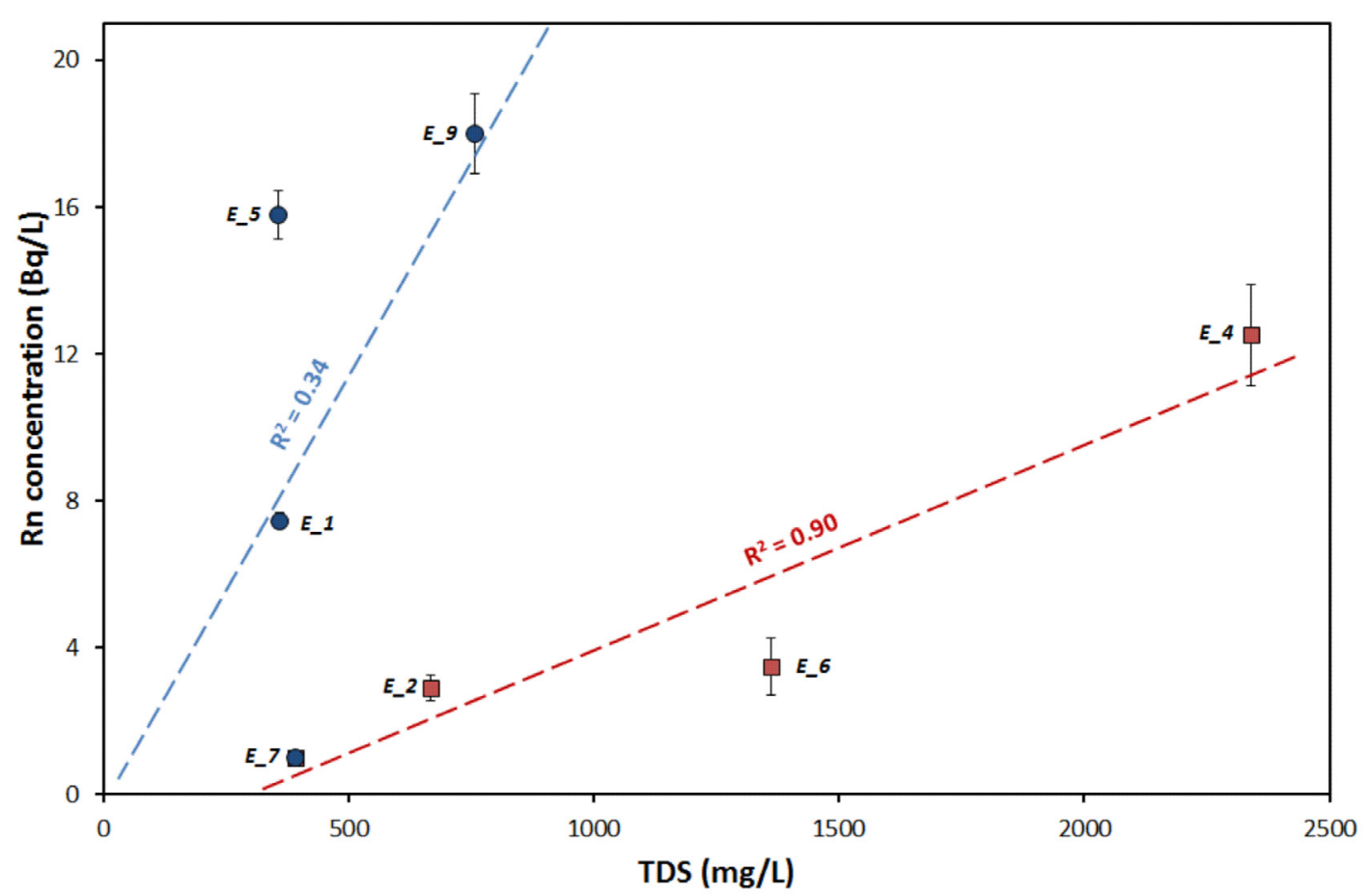

Figure 4. Correlation between average radon activity concentration in solution and TDS values in the sampled waters of Mt. Etna. The bestfit lines highlight two populations of samples related to two different mechanisms of radon input into solution (see text for explanation). Values of $\mathrm{R}^{2}$ correlation coefficient are also shown.

observed within the presently analyzed waters cannot be simply explained by the different content of parent radionuclides in the Etna volcanic rocks, due to the rather homogeneous chemical composition of the latter, but rather they can be a result of different natural factors related to interaction between volcanic gases, water and volcanic rocks. The first is the enhanced water-rock interaction in the eastern flank of Etna that causes a strong release of major ions (described by TDS values) and hence of radon as a by-product of radium decay. This factor, however, seems to be effective only for some of the sampled waters. Figure 4 shows the correlation between values of dissolved radon and values of TDS in all of our samples. As evident from the plot, our samples show two distinct behaviors. In fact, samples E_1, E_5 and E_9 apparently show a much poorer correlation between radon activity in water and the corresponding TDS values than the rest of our samples. These three water samples come from the same aquifer, so the plot suggests an additional input of radon in the aquifer represented by these samples and therefore a radon source other than a simple dissolution of volcanic rocks. To study this, we plotted radon activity values versus the corresponding $\mathrm{pCO}_{2}$ values in our water samples (Figure 5). Generally, the figure shows a correlation between the two parameters, indicating that radon activity in our sampled waters increases with increasing contents of dissolved $\mathrm{CO}_{2}$. This evidence, therefore, supports the idea that radon is carried by magmatic $\mathrm{CO}_{2}$ into the aquifers of the eastern flank of Etna, thus enriching water in both of these chemical species, and rules out the possibility of different radon $/ \mathrm{CO}_{2}$ ratios between the two group of samples highlighted in the plot of Figure 4. Therefore, a possible explanation for the higher-than-normal radon content in samples E_1, E_5 and E_9 is to assume that radon in these waters derives, if not solely at least in large part, from direct and strong input of magmatic gas in the aquifer in the proximity of these sampling sites. Actually, sites E_1 and E_5 are located very close to the Fiandaca Fracture Zone [Azzaro et al. 2012, De Guidi et al. 2012] and site E_9 is located very close to the Santa Venerina Fracture Zone [Azzaro et al. 2012, De Guidi et al. 2012], both being very active seismogenic faults. Therefore, it is reasonable to infer a large, $\mathrm{CO}_{2}$-driven, radon release into local groundwater through active shallow rock fracturing along those major structural lines.

A specific discussion must also be made for site E_4, due to its peculiar characteristics. According to the above indications, the high amount of radon previously measured by other authors in the waters from this site $\left({ }^{222} \mathrm{Rn}=43 \mathrm{~Bq} / \mathrm{L}\right)$ [D'Alessandro and Vita 2003] would stem both from enhanced dissolution of volcanic rocks and from strong direct input of $\mathrm{CO}_{2}$ gas into the aquifer, the latter testified by the very high $\mathrm{pCO}_{2}$ values calculated for this water. However, it is worth noting from Figure 5 that at site E_4 the radon activity value that we measured is much lower than that expected according to the observed general correlation with $\mathrm{pCO}_{2}$ 


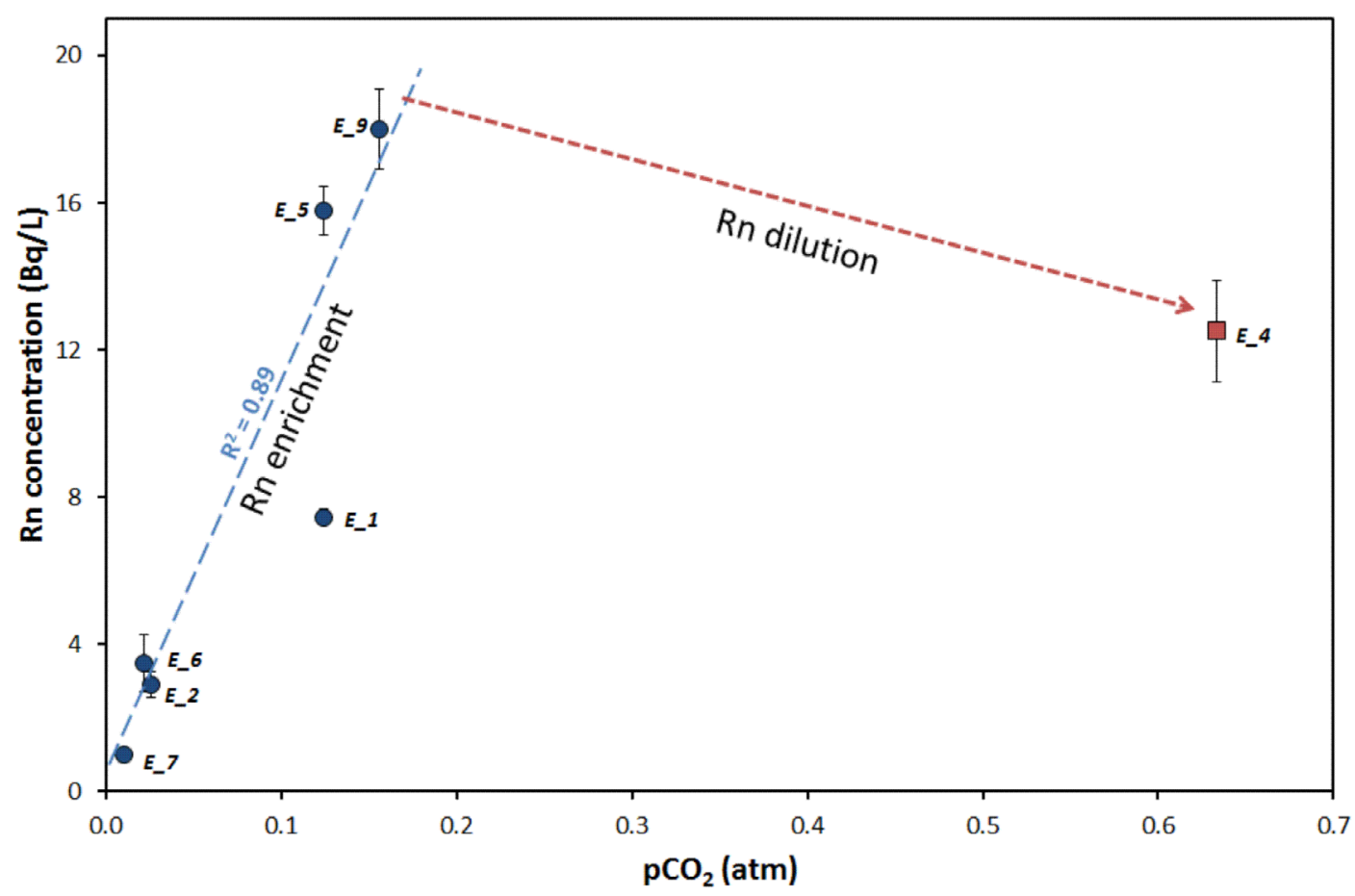

Figure 5. Correlation between radon activity in solution and $\mathrm{pCO}_{2}$ values in the sampled waters of Mt. Etna. The two lines show the main mechanism of radon enrichment and dilution produced by increasing input of volcanic $\mathrm{CO}_{2}$ into the aquifers (see text for explanation). The value of the $\mathrm{R}^{2}$ correlation coefficient for the best-fit line relevant to samples affected by radon enrichment is also shown.

values. Actually, if we remove the point corresponding to this site, the general correlation is greatly improved $(\mathrm{r}=+0.91)$, thus suggesting some physical mechanism acting in the water from site E_4 that either leads to a removal of radon from solution or that hampers radon dissolution into the ground water at very high values of dissolved $\mathrm{CO}_{2}$. The most reasonable explanation for this change in behavior is that the influx of the carrier gas $\left(\mathrm{CO}_{2}\right)$ in the ground water becomes so high that it overwhelms the shallow source of radon and thus dilutes it, so the gas entering the aquifer and dissolving into it has a much lower radon $/ \mathrm{CO}_{2}$ ratio. Actually, a similar process of radon dilution from high $\mathrm{CO}_{2}$ flux was already observed by Giammanco et al. [2007b] in soil and fumarole gas emissions from Mt. Etna and by Bonfanti et al. [1995] in soil gas samples from South East Sicily. In our case, the "dilution" effect would start at values of $\mathrm{pCO}_{2}$ higher than 0.2 atm (Figure 5).

Apart from the fact that the Mt. Etna waters can be treated as low radon activity waters, the values of the activity ratios ${ }^{222} \mathrm{Rn} /{ }^{238} \mathrm{U}$ in waters (Table 2) varied in a wide range from $50 \pm 11$ to $7856 \pm 1511$. The obtained results indicated that ${ }^{222} \mathrm{Rn}$ isotope was much better transported than ${ }^{238} \mathrm{U}$ isotope.

\section{Summary and conclusions}

This paper presents the first full description of radionuclides $\left({ }^{234} \mathrm{U},{ }^{238} \mathrm{U},{ }^{226} \mathrm{Ra},{ }^{228} \mathrm{Ra},{ }^{222} \mathrm{Rn}\right)$ contents in groundwaters of the eastern flank of Mt. Etna volcano and of radioactivity background $\left({ }^{226} \mathrm{Ra},{ }^{228} \mathrm{Ra}\right)$ in sur- rounding rocks. We studied nine groundwater samples from different local aquifers and eight rock samples from twelve localities altogether. Three groundwater samples were taken from water drainage galleries and six from water wells. All water intakes are used for drinkable purposes. Rock samples were assumed to represent the host rocks of local aquifers.

The present results confirmed those of a previous study performed on Mt. Etna [Kozłowska et al. 2009], taking into account a large number of aquifers, but with a much lower spatial density of sampling point in each aquifer. Activity concentrations of uranium isotopes ${ }^{234,238} \mathrm{U}$, radium isotopes ${ }^{226,228} \mathrm{Ra}$ and radon ${ }^{222} \mathrm{Rn}$ were determined with the use of different nuclear spectrometry techniques. Rocks surrounding the intakes were examined with gamma spectrometry.

Our new study showed that radionuclides levels in waters localized in the eastern flank of Mt. Etna are not different than the values obtained for the whole area of the volcano [Kozłowska et al. 2009]. Radionuclides are weakly leached by groundwater from the surrounding reservoir rocks, especially ${ }^{226,228} \mathrm{Ra}$ that were at levels below MDA. The average ${ }^{238} \mathrm{U}$ and ${ }^{234} \mathrm{U}$ activity concentrations were $21.3 \mathrm{mBq} / \mathrm{L}$ and $22.7 \mathrm{mBq} / \mathrm{L}$, respectively, whereas the average ${ }^{234} \mathrm{U} /{ }^{238} \mathrm{U}$ activity ratio was equal to 1.2 , thus proving achievement of secular equilibrium for uranium isotopes. Furthermore, all waters may be classified as low-radon waters, with maximum activity concentrations of $19.2 \pm 0.8 \mathrm{~Bq} / \mathrm{L}$.

Gamma spectrometry studies of the rock samples 
collected in the vicinity of water intakes showed ${ }^{226} \mathrm{Ra}$ and ${ }^{228} \mathrm{Ra}$ mean values equal to 61.8 and $53.3 \mathrm{~Bq} / \mathrm{kg}$, respectively. These values are slightly lower than those of volcanic rocks from other active volcanoes in this geographic area.

\section{References}

Acocella, V., and M. Neri (2003). What makes flank eruptions? The 2001 Etna eruption and its possible triggering mechanisms, B. Volcanol., 65, 517-529; doi:10.1007/s00445-003-0280-3.

Aiuppa, A., P. Allard, W. D’Alessandro, A. Michel, F. Parello, M. Treuil and M. Valenza (2000). Mobility and fluxes of major, minor and trace metals during basalt weathering and groundwater transport at Mt. Etna volcano (Sicily), Geochim. Cosmochim. Acta, 64, 1827-1841.

Aiuppa, A., P. Allard, W. D’Alessandro, S. Giammanco, F. Parello and M. Valenza (2004). Magmatic gas leakage at Mount Etna (Sicily, Italy): relationships with the volcano-tectonic structures, the hydrological pattern and the eruptive activity, In: Mt. Etna: Volcano Laboratory, A.G.U. Geophysical Monograph Series 143, 129-145; doi:10.1029/143GM09.

Allard, P., J. Carbonelle, D. Dajlevic, J. Bronce, P. Morel, M. Robe, J. Maurenads, R. Faivre-Pierret, D. Martin, J. Sabroux and P. Zettwoog (1991). Eruptive and diffuse emissions of $\mathrm{CO}_{2}$ from Mount Etna, Nature, 351, 387-391.

Allard, A., P. Jean-Baptiste, W. D’Alessandro, F. Parello, B. Parisi and C. Flehoc (1997). Mantle-derived helium and carbon in groundwaters and gases of Mount Etna, Italy, Earth Planet. Sc. Lett., 148, 501-516.

ANPA (2000). Il sistema informativo territoriale per la valutazione del potenziale di esalazione di esalazione di Radon dal suolo, ANPA-RT-00-009, ISBN: 88-4480284-8 (in Italian).

Anzà, S., G. Dongarrà, S. Giammanco, V. Gottini, S. Hauser and M. Valenza (1989). Geochimica dei fluidi dell'Etna: Le acque sotterranee, Miner. Petrogr. Acta, 32, 231-251 (in Italian).

ARPA Piemonte (2006). La radioattività ambientale in Piemonte - Rapporto anno 2005, Centro regionale radiazioni ionizzanti e non ionizzanti.

Azzaro, R., S. Branca, K. Gwinner and M. Coltelli (2012). Volcano-tectonic map of Etna volcano, Ital. J. Geosci., 131.

Bateman, H. (1910). Solution of a system of differential equations occurring in the theory of radioactive transformations, Proc. Cambridge Phil. Soc., 15, 423-427.

Bonfanti, P., M.L. Carapezza, W. D’Alessandro, R. De Domenico, I. Diliberto, R. Di Liberto, S. Giammanco,
S. Gurrieri, F. Parello and M. Valenza (1995). Earthquake of December 13, 1990 in eastern Sicily: Some geochemical investigations, In: V. Spagna and E. Schiavon (eds.), Proc. "Colloquio scientifico sulla Protezione Sismica" (Venice, July 1993), 176-184.

Brai, M., S. Basile, S. Bellia, S. Hauser, P. Puccio, S. Rizzo, A. Bartolotta and A. Licciardello (2002). Environmental radioactivity at Stromboli (Aeolian Islands), Appl. Radiat. Isot., 57, 99-107.

Branca, S., M. Coltelli and G. Groppelli (2011). Geological evolution of a complex basaltic stratovolcano: Mount Etna, Italy, Ital. J. Geosci., 130 (3), 306-317; doi:10.3301/IJG.2011.13.

Branca, S., and V. Ferrara (2013). The morphostructural setting of Mount Etna sedimentary basement (Italy): Implications for the geometry and volume of the volcano and its flank instability, Tectonophysics, 586, 46-64; doi:10.1016/j.tecto.2012.11.011.

Brusca, L., A. Aiuppa, W. D’Alessandro, F. Parello, P. Allard and A. Michel (2001). Geochemical mapping of magmatic gas-water-rock interactions in the aquifer of Mount Etna volcano, J. Volcanol. Geoth. Res., 108, 199-218.

Capaldi, G., M. Cortini, P. Gasparini and R. Pece (1976). Short-lived radioactive disequilibria in freshly erupted volcanic rocks and their implications for the preeruption history of a magma, J. Geophys. Res., 81 (2), 350-358.

Chester, D.K., A.M. Duncan, J.E. Guest and C.R.J. Kilburn (1985). Mount Etna: the anatomy of a volcano, Chapman and Hall, London.

Chiozzi, P., V. Pasquale, M. Verdoya and S. Minato (2001). Natural gamma-radiation in the Aeolian volcanic arc, Appl. Radiat. Isot., 55, 737-744.

Chiozzi, P., V. Pasquale, M. Verdoya and S. Minato (2003). Gamma-ray activity in the volcanic islands of the Southern Tyrrhenian Sea, J. Environ. Radioact., 67, 235-246.

Cristofolini, R., F. Lentini, G. Patanè and R. Rasà (1979). Integrazione di dati geologici, geofisici e petrologici per al stesura di un profilo crostale in corrispondenza dell'Etna, Boll. Soc. Geol. It., 98, 239-247 (in Italian).

Cristofolini, R., and R. Romano (1982). Petrologic features of the Etnean volcanic rocks, Mem. Soc. Geol. It., 23, 99-115.

Cothern, C.R., W.L. Lappenbusch and J. Michel (1986). Drinking water contribution to natural background, Health Phys., 50, 33-39.

Cothern, C.R., and J.E. Smith Jr., eds. (1987). Environmental radon, Plenum Press, New York.

Currie, L.A. (1968). Limits for qualitative detection and quantitative determination, Anal. Chem., 40 (3), 
586-592

D’Alessandro, W., S. Giammanco, F. Parello and M. Valenza (1997). $\mathrm{CO}_{2}$ output and $\mathrm{d}^{13} \mathrm{C}\left(\mathrm{CO}_{2}\right)$ from Mount Etna as indicators of degassing of shallow asthenosphere, B. Volcanol., 58, 455-458.

D’Alessandro, W., and F. Vita (2003). Groundwater radon measurements in the Mt. Etna area, J. Environ. Radioact., 65, 187-201.

Darby, S., D. Hill, A. Auvinen, J.M. Barros-Dios, H. Baysson, F. Bochicchio, H. Deo, R. Falk, F. Forastiere, M. Hakama, I. Heid, L. Kreienbrock, M. Kreuzer, F. Lagarde, I. Mäkeläinen, C. Muirhead, W. Oberaigner, G. Pershagen, A. Ruano-Ravina, E. Ruosteenoja, A. Schaffrath Rosario, M. Tirmarche, L. TomáBek, E. Whitley, H.E. Wichmann and R. Doll (2005). Radon in homes and risk of lung cancer: collaborative analysis of individual data from 13 European casecontrol studies, B.M.J., 330, 223; doi:10.1136/bmj. 38308.477650 .63

Dávila Rangel, J.I., H. López Del Río, F. Mireles García, L.L. Quirino Torres, M.L. Villalba, L. Colmenero Sujo and M.E. Monterro Cabrera (2002). Radioactivity in bottled waters sold in Mexico, Appl. Radiat. Isot., 56, 931-936.

De Guidi, G., S. Scudero and S. Gresta (2012). New insights into the local crust structure of Mt. Etna volcano from seismological and morphotectonic data, J. Volcanol. Geoth. Res., 223-224, 83-92; doi:10.1016/ j.jvolgeores.2012.02.001.

Dongarrà, G., V. Gottini, M. Valenza and P. Bonfanti (1993). Progress in hydrogeochemistry surveying, Acta Vulcanol., 3, 318-321.

EPA (2000). Environmental Protection Agency, National Primary Drinking Water Regulations; Radionuclides; Final Rule, Federal Register, 65 (236), December 7.

Ferrara, V. (1990). Carta della vulnerabilità all'inquinamento dell'acquifero vulcanico dell'Etna, C.N.R. Valutazione della Vulnerabilità degli Acquiferi, S.EL.CA., Firenze (in Italian).

Ferrara, V., and G. Pappalardo (2008). The hydrogeological map of the Etna volcanic massif as useful tool for groundwater resources management, It. J. Eng. Geol. Environ., 1, 77-89 (Special issue).

Giammanco, S., S. Gurrieri and M. Valenza (1995). Soil $\mathrm{CO}_{2}$ degassing on Mt. Etna (Sicily) during the period 1989-1993: discrimination between climatic and volcanic influences, B. Volcanol., 57, 52-60.

Giammanco, S., M. Valenza, S. Pignato and G. Giammanco (1996). Mg, Fe, Mn and V concentrations in the ground waters of Mount Etna (Sicily), Water Res., 2, 378-386.

Giammanco, S., M. Ottaviani, M. Valenza, E. Veschetti,
E. Principio, G. Giammanco and S. Pignato (1998). Major and trace elements geochemistry in the ground waters of a volcanic area: Mount Etna (Sicily), Water Res., 32, 19-30.

Giammanco, S., M. Ottaviani and E. Veschetti (2007a). Temporal variability of major and trace elements concentrations in the ground waters of Mt. Etna (Italy): evidence of transient input of magmatic fluids highlighted by means of Cluster Analysis, Pure Appl. Geophys., 164, 2523-2547.

Giammanco, S., K.W.W. Sims and M. Neri (2007b). Measurements of ${ }^{220} \mathrm{Rn}$ and ${ }^{222} \mathrm{Rn}$ and $\mathrm{CO}_{2}$ emissions in soil and fumarole gases on Mt. Etna volcano (Italy): Implications for gas transport and shallow ground fracture, Geochem. Geophys. Geosys., 8 (10); doi:10.1029/2007GC001644.

Godoy, J.M., and M.L. Godoy (2006). Natural radioactivity in Brazilian groundwater, J. Environ. Radioact., 85, 71-83.

IAEA - CU - 2008-03 (2010). World-wide open proficiency test on the determination of natural radionuclides in phosphogypsum and spiked water, I.A.E.A., Vienna; http: / / www.iaea.org/programmes/aqcs / interlab_studies.shtml.

IARC (1988). IARC monographs on the evaluation of carcinogenic risks to humans, Man-made Mineral Fibres and Radon, 43, 177-178.

Jia, G., G. Torri and L. Magro (2009). Concentrations of ${ }^{238} \mathrm{U},{ }^{234} \mathrm{U},{ }^{235} \mathrm{U},{ }^{232} \mathrm{Th},{ }^{230} \mathrm{Th},{ }^{228} \mathrm{Th},{ }^{226} \mathrm{Ra},{ }^{228} \mathrm{Ra}$, ${ }^{224} \mathrm{Ra},{ }^{210} \mathrm{Po},{ }^{210} \mathrm{~Pb}$ and ${ }^{212} \mathrm{~Pb}$ in drinking water in Italy: reconciling safety standards based on measurements of gross $\alpha$ and $\beta$, J. Environ. Radioact., 100, 941-949.

Kozłowska, B., A. Walencik and J. Dorda (2008). Natural radioactivity and dose estimation in underground water from the Sudety mountains in Poland, Radiat. Prot. Dosimetry, 128 (3), 331-335.

Kozłowska, B., D. Morelli, A. Walencik, J. Dorda, I. Altamore, V. Chieffalo, S. Giammanco, G. Immè and W. Zipper (2009). Radioactivity in waters of Mt. Etna (Italy), Radiat. Meas., 44, 384-389.

Kozłowska, B., A. Walencik, J. Dorda and W. Zipper (2010). Natural radionuclides in bottled mineral and table waters in Poland, Polish J. Environ. Studies, 1, Series of Monographs - Some Aspects Of Medical Physics - In Vivo And In Vitro Studies, Hard, 132-138.

Kozłowska, B., A. Walencik, J. Dorda and W. Zipper (2012). Radioactivity of dumps in mining areas of the Upper Silesian Coal Basin in Poland, Nuovo Cimento, Proceedings, EPJ Web of Conferences; doi:10.1051/ epjconf/20122405006.

Kralik, C., M. Friedrich and F. Vojir (2003). Natural radionuclides in bottled water in Austria, J. Environ. 
Radioact., 65, 233-241.

Martín Sánchez, A., M.P. Rubio Montero, V. Gómez Escobar and M. Jurado Vargas (1999). Radioactivity in bottled mineral waters, Appl. Radiat. Isot., 50, 10491055 .

Möbius, S., and L. Salonen (2002). Pilot intercomparison and workshop for radon and radium in natural water, In: S. Möbius, J.E. Noakes and F. Schönhofer (eds.), LSC 2001, Advances in Liquid Scintillation Spectrometry, Radiocarbon., 327-324.

Neri, M., S. Giammanco, E. Ferrera, G. Patanè and V. Zanon (2011). Spatial distribution of soil radon as a tool to recognize active faulting on an active volcano: the example of Mt. Etna (Italy), J. Environm. Rad., 102, 863-870; doi:10.1016/j.jenvrad.2011.05.002.

Nevissi, A.E., and D. Bodansky (1987). Radon sources and levels in the outside environment, In: D. Bodansky, M.A. Robkin and D.R. Stadler (eds.), Indoor radon and its hazards, University of Washington Press, Seattle and London.

Ogniben, L. (1966). Lineamenti idrogeologici dell'Etna, Riv. Min. Sic., 100-102, 1-24 (in Italian).

Osmond, J.K., J.B. Coward and M. Ivanovich (1983). Uranium isotopes disequilibrium in ground water as an indicator of anomalies, Appl. Radiat. Isot., 34 (1), 283-308.

Parello, F., W. D’Alessandro, A. Aiuppa and C. Federico (2001). Cartografia geochimica degli acquiferi Etnei, C.N.R., G.N.D.C.I., Publ. N. 2190, 104 p. (in Italian).

Plant, J.A., S. Reeder, R. Salminen, D.B. Smith, T. Tarvainen, B. De Vivo and M.G. Peterson (2003). The distribution of uranium over Europe: geological and environmental significance, Appl. Earth Sci. (Trans. Inst. Min. Metall. B), 112, 221-238.

Polański, A. (1988). Podstawy geochemii, Wydawnictwa geologiczne, Warsaw (in Polish).

Polish Norm PN-89/ZN-70072 (1989). Radium isotopes determination in water with LSC method, Wydawnictwa Normalizacyjne "Alfa", Warsaw (in Polish).

Radiological Atlas of Poland (2012). Warszawa. K. Isajenko, B. Piotrowska, M. Fujak and M. Karda , Central Laboratory for Radiological Protection, Biblioteka Monitoringu rodowiska.

Romano, R. (1982). Succession of the volcanic activity in the Etnean area, Mem. Soc. Geol. It., 23, 27-48.

Schilirò, F. (1988). Proposta metodologica per una zonazione geologico-tecnica del centro abitato di Maletto, Geologia Tecnica, 3 / 88, 32-53 (in Italian).

Sill, C.W. (1987). Precipitation of actinides as fluorides or hydroxides for high resolution alpha spectrometry, Nuclear Chem. Waste Mgmt., 7.

Suomela, J. (1993a). Method for Determination of
Radon-222 in Water by Liquid Scintillation Counting. SSI-rapport 93-13, ISO Norm: ISO/TC147/SC3 / WG6Work, Swedish Radiation Protection Institute, Stockholm, Sweden.

Suomela, J. (1993b). Method for Determination of UIsotopes in Water, Swedish Radiation Protection Institute, Stockholm, Sweden.

Walencik, A., B. Kozłowska, T.A. Przylibski, J. Dorda and W. Zipper (2010). Natural radioactivity of groundwater from the Przerzeczyn-Zdrój Spa, Nukleonika, 55 (2), 169-175.

Walencik, A., B. Kozłowska, J. Dorda and W. Zipper (2012). Long lived natural radioactive elements in spa waters of southern Poland - dose assessment and health hazard evaluation, Acta Physica Polonica, B43 (2), 345-350.

WHO (2011). Guidelines for drinking water quality, World Health Organization.

\footnotetext{
${ }^{\star}$ Corresponding author: Beata Kozłowska, University of Silesia, Institute of Physics, Department of Nuclear Physics and Its Applications, Katowice, Poland; email: beata.kozlowska@us.edu.pl.

(C) 2016 by the Istituto Nazionale di Geofisica e Vulcanologia. All rights reserved.
} 